\title{
The significance of glucosinolates for sulfur storage in Brassicaceae seedlings
}

\author{
Tahereh Aghajanzadeh ${ }^{1}$, Malcolm J. Hawkesford ${ }^{2}$ and Luit J. De Kok ${ }^{1 *}$ \\ ${ }^{1}$ Laboratory of Plant Physiology, University of Groningen, Groningen, Netherlands \\ 2 Plant Biology and Crop Science Department, Rothamsted Research, Harpenden, UK
}

\section{Edited by:}

Agnieszka Sirko, Institute of

Biochemistry and Biophysics - Polish

Academy of Sciences, Poland

\section{Reviewed by:}

Doug Van Hoewyk, Coastal Carolina University, USA

Elke Bloem, Julius Kühn-Institute Institute for Crop and Soil Science, Germany

\section{${ }^{*}$ Correspondence:}

Luit J. De Kok, Laboratory of Plant Physiology, University of Groningen, P.O. Box 11103, Groningen 9700 CC Netherlands

e-mail: I.j.de.kok@rug.nI
Brassica juncea seedlings contained a twofold higher glucosinolate content than $B$. rapa and these secondary sulfur compounds accounted for up to $30 \%$ of the organic sulfur fraction. The glucosinolate content was not affected by $\mathrm{H}_{2} \mathrm{~S}$ and $\mathrm{SO}_{2}$ exposure, demonstrating that these sulfur compounds did not form a sink for excessive atmospheric supplied sulfur. Upon sulfate deprivation, the foliarly absorbed $\mathrm{H}_{2} \mathrm{~S}$ and $\mathrm{SO}_{2}$ replaced sulfate as the sulfur source for growth of $B$. juncea and $B$. rapa seedlings. The glucosinolate content was decreased in sulfate-deprived plants, though its proportion of organic sulfur fraction was higher than that of sulfate-sufficient plants, both in absence and presence of $\mathrm{H}_{2} \mathrm{~S}$ and $\mathrm{SO}_{2}$. The significance of myrosinase in the in situ turnover in these secondary sulfur compounds needs to be questioned, since there was no direct co-regulation between the content of glucosinolates and the transcript level and activity of myrosinase. Evidently, glucosinolates cannot be considered as sulfur storage compounds upon exposure to excessive atmospheric sulfur and are unlikely to be involved in the re-distribution of sulfur in $B$. juncea and $B$. rapa seedlings upon sulfate deprivation.

Keywords: Brassicaceae, glucosinolate, hydrogen sulfide, myrosinase activity and expression, sulfur deficiency, sulfur dioxide, sulfur storage

\section{INTRODUCTION}

Glucosinolates are secondary sulfur compounds commonly found in relatively high levels in shoots, roots, and seeds of Brassicaceae and may account for up to $20 \%$ of the organic sulfur fraction (Schnug, 1990, 1993; Fahey et al., 2001; Castro et al., 2004; Halkier and Gershenzon, 2006; Clay et al., 2009; Del Carmen MartinezBallesta etal., 2013). These secondary sulfur compounds are responsible for the spicy flavor of many species of the Brassicaceae, e.g., mustard and radish (Schnug, 1990, 1993). Glucosinolates are derived from amino acids and have a core structure consisting of a $\beta$-D-glucopyranose residue linked to a $(Z)-N$-hydroximino sulfate ester via a sulfur atom and a variable side chain (Halkier and Gershenzon, 2006). On the basis of their precursor amino acids, specific aliphatic, indolyl, and aromatic glucosinolates can be distinguished, and furthermore Brassica species differ strongly in content and composition of these glucosinolates (Castro et al., 2004; Halkier and Gershenzon, 2006).

The glucosinolate content may be affected by the sulfur nutritional status of the plant; supplemental sulfur fertilization of Brassica in greenhouse and field experiments resulted in an up to a 20-fold increase in glucosinolate content in foliar tissues (Falk et al., 2007). However, the impact of sulfur fertilization on glucosinolate content varied strongly between plant species, growth stage and organs, and the rate of sulfur supplied (Kirkegaard and Sarwar, 1998; Castro et al., 2004; Falk et al., 2007; Antonious et al., 2009). For instance, in some cultivars of broccoli, sulfur fertilization only resulted in an increase in glucosinolate content in the heads, whereas in other cultivars it had no effect or even resulted a lower glucosinolate content (Falk et al., 2007).
Upon cellular injury, glucosinolates are enzymatically degraded by myrosinase (a thioglucosidase), resulting in a variety of breakdown products, including glucose, sulfate, and depending on specific chemical structure, isothiocyanates, nitriles, epithionitriles, oxazolidinethions, indolyl alcohols, thiocyanate, and amines (Fenwick et al., 1983; Halkier and Du, 1997; Bones and Rossiter, 2006; Halkier and Gershenzon, 2006; Kissen and Bones, 2009; Kissen etal., 2009; Ahuja et al., 2010). It is presumed that both glucosinolates and their breakdown products may play a role in the defense of plants against microorganisms, fungi, and insects (Ernst, 1993; Bones and Rossiter, 1996; Ahuja et al., 2010). Moreover, glucosinolates are presumed to have a sulfur storage role in plants and their degradation by myrosinase might have significance in the re-distribution of sulfur in plants under sulfurdeprived conditions (Schnug, 1990; Hirai et al., 2004, 2005; Bloem et al., 2007; Falk et al., 2007).

In addition to sulfate taken up by the roots, plants are able to utilize foliarly absorbed sulfur gases as a supplemental sulfur source for growth (De Kok et al., 2000a, 2007, 2009). For instance, continuous exposure of Brassica to atmospheric $\mathrm{H}_{2} \mathrm{~S}$ or $\mathrm{SO}_{2}$ levels of $\geq 0.2 \mu \mathrm{ll}^{-1}$ was sufficient to cover the organic sulfur requirement to maintain growth in the absence of sulfate in the root environment (De Kok et al., 2000b, 2002; Yang et al., 2006a,b; Koralewska et al., 2008). In the current study, the impacts of sulfur nutrition (atmospheric and pedospheric) on the glucosinolate content and the transcript levels and activity of myrosinase were studied in seedlings of two Brassica species, which are characterized by a high (Brassica juncea, mustard greens) and low (B. rapa, mustard spinach) glucosinolate content. The aim of the study was to gain insight into the significance of glucosinolates in sulfur 
storage and the role of myrosinase in the re-distribution of sulfur in sulfate-deprived plants.

\section{MATERIALS AND METHODS PLANT MATERIAL AND $\mathrm{H}_{2} \mathrm{~S}$ AND $\mathrm{SO}_{2}$ EXPOSURE}

Seeds of $B$. juncea cv. Rugosa and B. rapa cv. Komatsuna; Van der Wal, Hoogeveen, The Netherlands) were germinated in vermiculite in a climate-controlled room. Day and night temperatures were 22 and $18^{\circ} \mathrm{C}\left( \pm 1^{\circ} \mathrm{C}\right)$, respectively, relative humidity was $60-70 \%$. The photoperiod was $14 \mathrm{~h}$ at a photon fluence rate of $300 \pm 20 \mu \mathrm{mol} \mathrm{m} \mathrm{m}^{-2} \mathrm{~s}^{-1}(400-700 \mathrm{~nm})$ at plant height, supplied by Philips GreenPower LED (deep red/white 120) production modules. Ten day-old seedlings were transferred to an aerated 25\% Hoagland nutrient solution at $0.5 \mathrm{mM}$ sulfate for 3 days and subsequently transferred to fresh Hoagland nutrient solution at $0 \mathrm{mM}$ sulfate $(-\mathrm{S}$, sulfate-deprived) or $0.5 \mathrm{mM}$ sulfate $(+\mathrm{S}$, sulfate-sufficient) in 131 stainless steel containers (10 sets of plants per container; three plants per set). Plants were

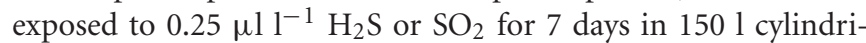
cal stainless steel cabinets $(0.6 \mathrm{~m}$ diameter $)$ with a polymethyl methacrylate top. Sealing of the lid of the container and plant sets prevented absorption of atmospheric $\mathrm{H}_{2} \mathrm{~S}$ or $\mathrm{SO}_{2}$ by the solution. Day and night temperatures were 24 and $20^{\circ} \mathrm{C}\left( \pm 2^{\circ} \mathrm{C}\right)$, respectively, and relative humidity was $40-50 \%$. The photoperiod was $14 \mathrm{~h}$ at a photon fluence rate of $300 \pm 20 \mu \mathrm{mol} \mathrm{m}^{-2} \mathrm{~s}^{-1}$ (400-700 nm) at plant height, supplied by Philips GreenPower LED (deep red/white 120) production modules. The temperature inside the cabinets was controlled by adjusting the cabinet wall temperature. The air exchange was $401 \mathrm{~min}^{-1}$ and the air inside the cabinets was stirred continuously by a ventilator. Pressurized $\mathrm{H}_{2} \mathrm{~S}$ and $\mathrm{SO}_{2}$ diluted with $\mathrm{N}_{2}\left(1 \mathrm{ml} \mathrm{l}^{-1}\right)$ was injected into the incoming air stream and their concentration in the cabinet was adjusted to the desired level using electronic mass flow controllers (ASM, Bilthoven, The Netherlands). The sulfur gas level in the cabinets was monitored by an $\mathrm{SO}_{2}$ analyzer (model 9850) equipped with a $\mathrm{H}_{2} \mathrm{~S}$ converter (model 8770; Monitor Labs, Measurement Controls Corporation, Englewood, CO, USA). Plants were harvested $3 \mathrm{~h}$ after the onset of the light period and the roots were rinsed in ice-cold demineralized water (for $3 \times 20$ s). Roots were separated from the shoots, weighed, and for glucosinolate, myrosinase activity and RNA isolation, plant material was frozen immediately in liquid $\mathrm{N}_{2}$ and stored at $-80^{\circ} \mathrm{C}$. For analysis of dry matter, sulfate, and total sulfur, plant tissue was dried at $80^{\circ} \mathrm{C}$ for $24 \mathrm{~h}$.

\section{TOTAL SULFUR AND SULFATE CONTENT}

The total sulfur content was analyzed using a modification of the method as described by Jones (1995). Dried shoots and roots were pulverized in a Retsch Mixer-Mill (Retsch type MM2; Haan, Germany) and 50-150 mg of the samples was weighed into porcelain ashing trays. A $50 \% \mathrm{Mg}\left(\mathrm{NO}_{3}\right)_{2} \cdot 6 \mathrm{H}_{2} \mathrm{O}(\mathrm{w} / \mathrm{v})$ solution was added until saturation of the material, and was dried overnight in an oven at $100^{\circ} \mathrm{C}$. Subsequently, the samples were ashed in an oven at $650^{\circ} \mathrm{C}$ for $12 \mathrm{~h}$. The residues were dissolved in 5 or $10 \mathrm{ml}$ of $20 \%$ aqua regia $\left(50 \mathrm{ml}\right.$ conc. $\mathrm{HNO}_{3}$ and $150 \mathrm{ml}$ conc. $\mathrm{HCl}$ in $1 \mathrm{l}$ demineralized water) and quantitatively transferred to a volumetric flask and made up to 50 or $100 \mathrm{ml}$ with demineralized water. One SulphaVer ${ }^{\circledR} 4$ Reagent Powder Pillow (HACH, Permachem ${ }^{\circledR}$ reagents, Loveland, USA) containing $\mathrm{BaCl}_{2}$ was added to 10 or $25 \mathrm{ml}$ of extract, and the turbidity was measured with a spectrophotometer (HACH DR/400V, Loveland, CO, USA) at $450 \mathrm{~nm}$. For measurement of the sulfate content, pulverized dried plant material was incubated for $3-4 \mathrm{~h}$ in demineralized water $(10 \mathrm{mg} / \mathrm{ml})$ at $50^{\circ} \mathrm{C}$ (Tausz et al., 1996; Yang et al., 2006a,b) and centrifuged at 30,000 $\mathrm{g}$ for $15 \mathrm{~min}$. Anions were separated by HPLC on an Agilent IonoSpher 5A anion exchange column $(250 \times 4.6 \mathrm{~mm}$; Agilent Technologies, Amstelveen, The Netherlands) and sulfate content was determined refractometrically according to Maas et al. (1986). The HPLC system consisted of a Knauer HPLC pump model 100 and a Knauer differential refractometer model 98.00 (Knauer, Berlin, Germany). The mobile phase contained $25 \mathrm{mM}$ potassium biphthalate $\left(\mathrm{pH} 4.3\right.$ ) with $0.02 \% \mathrm{NaN}_{3}(\mathrm{w} / \mathrm{v})$. There were no significant differences in sulfate content determined in dried and fresh plant material of B. juncea and B. rapa. This indicated that there was no increase in sulfate content in dried plant material caused by the degradation of glucosinolates. The organic sulfur content was calculated by subtracting the sulfate content from the total sulfur content determined in the same tissue sample.

\section{GLUCOSINOLATE CONTENT}

The glucosinolates were extracted and determined according to a modified method of Heaney and Fenwick (1980) and O'Callaghan et al. (2000). Frozen plant material was freeze-dried in a LyoLAB 3000 freeze drier (Heto-Holten A/S, Allerød, Denmark) for 3 days. Freeze-dried plant samples were pulverized in a Retsch MixerMill (Retsch type MM2; Haan, Germany). The glucosinolates were extracted in boiling 90\% methanol (50 $\mathrm{mg}$ in $3 \mathrm{ml}$ ) for $2 \mathrm{~min}$. The extract was centrifuged for $2 \mathrm{~min}$ at $2,500 \mathrm{~g}$ and the residue was re-extracted twice with $3 \mathrm{ml}$ boiling 70\% methanol. Total glucosinolate content was determined based on its reaction with sodium tetrachloropalladate II $\left(\mathrm{Na}_{2} \mathrm{PdCl}_{4}\right.$; Gupta et al., 2012; Ishida et al., 2012). The reaction mixture containing $60 \mu \mathrm{l}$ extract and $1800 \mu \mathrm{l} 2 \mathrm{mM} \mathrm{Na}_{2} \mathrm{PdCl}_{4}$ was incubated at $20^{\circ} \mathrm{C}$ for $30 \mathrm{~min}$ and the absorbance of the developed color measured colorimetrically at $450 \mathrm{~nm}$ (Thies, 1982). Sinigrin (Sigma-Aldrich, S1647) was used as an internal standard for all samples $(13 \mu \mathrm{mol}$ per extracts) and data were corrected for recovery rate (always higher than $80 \%$ ).

\section{MYROSINASE ACTIVITY}

The myrosinase activity was determined by the photometric quantification of released glucose with sinigrin (2-propenyl glucosinolate, S1647, Sigma-Aldrich) as substrate, as described by Travers-Martin et al. (2008). Frozen plant material was homogenized in $200 \mathrm{mM}$ Tris-HCl, 10 mM EDTA, pH 7.0 ( $1 \mathrm{~g}$ fresh weight per $5 \mathrm{ml}$ ) at $0^{\circ} \mathrm{C}$ with an Ultra Turrax (T25, IKA Werke, Staufen, Germany) and filtered through one layer of Miracloth. The filtered extract was centrifuged at $16,000 \mathrm{~g}$ at $4^{\circ} \mathrm{C}$ for $15 \mathrm{~min}$. The reaction mixture contained a final volume one $\mathrm{ml}, 150 \mu \mathrm{l}$ supernatant and $1 \mathrm{mM}$ sinigrin and was incubated at $25^{\circ} \mathrm{C}$ for $30 \mathrm{~min}$. The reaction was stopped by incubating the reaction mixtures at $100^{\circ} \mathrm{C}$ for $10 \mathrm{~min}$. Subsequently the reaction mixtures were centrifuged 
at $10,000 \mathrm{~g}$ at room temperature for $10 \mathrm{~min}$ and the content of glucose in the supernatant was determined by using an enzymatic glucose assay kit (Sigma-Aldrich). The soluble protein content was determined by the method of Bradford (1976) using bovine serum albumin as a standard.

\section{RNA EXTRACTION AND REAL-TIME OUANTITATIVE PCR OF MYROSINASE}

Total RNA was isolated by a modified hot phenol method (Verwoerd et al., 1989). Frozen ground plant material was extracted in hot $\left(80^{\circ} \mathrm{C}\right)$ phenol/extraction buffer $(1: 1, \mathrm{v} / \mathrm{v}), 1 \mathrm{~g} \mathrm{ml}^{-1}$. The extraction buffer contained $0.1 \mathrm{M}$ Tris- $\mathrm{HCl}, 0.1 \mathrm{M} \mathrm{LiCl}, 1 \%$ SDS (w/v), 10 mM EDTA, pH 8.0). After mixing, $0.5 \mathrm{ml}$ of chloroformisoamyl alcohol $(24: 1, \mathrm{v} / \mathrm{v})$ was added. After centrifugation $(13,400 \mathrm{~g})$ for $5 \mathrm{~min}$ at $4^{\circ} \mathrm{C}$, the aqueous phases were transferred to new tube. After adding an equal volume of chloroform and isoamyl alcohol, the total RNA was precipitated by $4 \mathrm{M} \mathrm{LiCl}$ overnight at $4^{\circ} \mathrm{C}$. Total RNA was collected and washed with $70 \%$ ethanol. Possible genomic DNA contamination was removed with a DNase treatment step (Promega, USA). Phenol-chloroformisoamyl alcohol and chloroform-isoamyl alcohol were used for further purification and total RNA was precipitated by ethanol and dissolved in diethylpyrocarbonate-treated water. The quantity and quality of RNA was checked using ThermoNanoDrop 2000 and RNA in each was adjusted to the same concentration. The integrity of RNA was checked by electrophoresis by loading $1 \mu \mathrm{g}$ RNA on a $1 \%$ TAE-agarose gel.

DNA-free intact RNA ( $1 \mu \mathrm{g})$ was reverse transcribed into cDNA with oligo-dT primers using a first strand cDNA synthesis kit (Promega, USA) according to the manufacture-supplied instructions. Subsequently, the cDNA was used as a template in real-time PCR experiments with gene-specific primers. To design primers, the full length complementary DNA of the Arabidopsis genes, actin (reference gene) and myrosinase (TGG1 and TGG2), which are mostly expressed in the shoot (Andersson et al., 2009), were used to query homologous B. juncea and B. rapa sequences. Expressed sequence tags (ESTs) were obtained from the publically available platform at NCBI. The primer sequences used for myrosinase and actin were (F 5'-CCGGTCGATGTTCTCCTAT-3', R 5' -GAAGAAT TTCCACCGTAACAC- $3^{\prime}$ ) and (F 5'-AGCAGCATGAAGATCAAG GT-3', R 5'-GCTGAGGGATGCAAGGATAG-3'), respectively. RTPCR was performed on Applied Bio Systems' 7300 real-time PCR system using the SYBR Green master mix kit (Thermo Scientific) based on manufacturer's instructions. The transcript level of the target gene and actin was measured using the comparative Ct method. Analysis of qPCR data was performed using three independent RNA preparations from separate plant shoots.

\section{STATISTICAL ANALYSIS}

Data from different experimental sets ware analyzed for statistical significance using an unpaired two-tailed Student's $t$-test $(P<0.01)$.

\section{RESULTS \\ IMPACT OF ATMOSPHERIC AND PEDOSPHERIC SULFUR NUTRITION ON GROWTH AND SULFUR CONTENT}

Exposure of B. juncea and B. rapa to $0.25 \mu l \mathrm{l}^{-1} \mathrm{H}_{2} \mathrm{~S}$ and $0.25 \mathrm{Mll}^{-1} \mathrm{SO}_{2}$ for 7 days did not significantly affect plant biomass production, shoot to root ratio, and dry matter content (DMC) of shoots and roots at sulfate-sufficient conditions (Table 1). In addition, $\mathrm{H}_{2} \mathrm{~S}$ exposure did not affect the total sulfur, sulfate, and organic sulfur content of the shoots and roots of both species (Figure 1). Moreover $\mathrm{SO}_{2}$ exposure also

Table 1 | Impact of $\mathrm{H}_{2} \mathrm{~S}, \mathrm{SO}_{2}$ and sulfate deprivation on biomass production and dry matter content (DMC) of shoots and roots of $B$. juncea and B. rapa.

\begin{tabular}{|c|c|c|c|c|c|c|}
\hline & $+\mathbf{S}$ & $+\mathrm{S}+\mathrm{H}_{2} \mathrm{~S}$ & $+\mathrm{S}+\mathrm{SO}_{2}$ & $-\mathbf{S}$ & $-\mathrm{S}+\mathrm{H}_{2} \mathrm{~S}$ & $-\mathrm{S}+\mathrm{SO}_{2}$ \\
\hline \multicolumn{7}{|l|}{ B. juncea } \\
\hline Shoot biomass production & $0.71 \pm 0.18 a$ & $0.75 \pm 0.27 a$ & $0.65 \pm 0.19 a$ & $0.34 \pm 0.08 b$ & $0.66 \pm 0.10 a$ & $0.71 \pm 0.17 a$ \\
\hline Root biomass production & $0.14 \pm 0.05 c$ & $0.13 \pm 0.04 c$ & $0.13 \pm 0.05 c$ & $0.16 \pm 0.06 \mathrm{bc}$ & $0.20 \pm 0.05 a b$ & $0.23 \pm 0.09 a$ \\
\hline Shoot DMC & $10.4 \pm 1.1 \mathrm{a}$ & $9.8 \pm 0.8 a$ & $10.4 \pm 1.1 \mathrm{a}$ & $11.3 \pm 1.1 \mathrm{a}$ & $9.7 \pm 0.6 a$ & $10.0 \pm 0.5 a$ \\
\hline Root DMC & $8.9 \pm 0.7 a$ & $7.9 \pm 1.7 a b$ & $8.1 \pm 1.3 a$ & $6.1 \pm 1.0 b$ & $6.8 \pm 0.7 b$ & $5.8 \pm 0.8 b$ \\
\hline Shoot/root ratio & $5.3 \pm 0.7 a$ & $5.7 \pm 1.2 \mathrm{a}$ & $5.2 \pm 0.9 a$ & $2.2 \pm 0.5 c$ & $3.9 \pm 0.6 b$ & $3.0 \pm 0.6 b c$ \\
\hline \multicolumn{7}{|l|}{ B. rapa } \\
\hline Shoot biomass production & $1.14 \pm 0.28 a$ & $1.07 \pm 0.27 a$ & $0.90 \pm 0.26 \mathrm{ab}$ & $0.37 \pm 0.17 c$ & $0.74 \pm 0.30 b$ & $0.78 \pm 0.22 b$ \\
\hline Root biomass production & $0.19 \pm 0.06 a b$ & $0.16 \pm 0.05 b$ & $0.15 \pm 0.04 b$ & $0.13 \pm 0.06 c$ & $0.19 \pm 0.07 a b$ & $0.23 \pm 0.08 a$ \\
\hline Shoot DMC & $9.5 \pm 0.5 b$ & $9.3 \pm 0.6 b$ & $9.8 \pm 0.4 b$ & $11.7 \pm 1.2 \mathrm{a}$ & $9.6 \pm 0.8 b$ & $9.8 \pm 0.7 a b$ \\
\hline Root DMC & $7.2 \pm 1.4 a$ & $7.8 \pm 1.3 a$ & $7.3 \pm 0.8 a$ & $8.2 \pm 2.3 a$ & $7.5 \pm 1.1 \mathrm{a}$ & $7.2 \pm 0.6 a$ \\
\hline Shoot/root ratio & $6.0 \pm 1.0 a$ & $7.0 \pm 1.2 a$ & $6.2 \pm 0.5 a$ & $2.9 \pm 0.8 c$ & $4.0 \pm 0.8 b c$ & $3.5 \pm 0.6 b c$ \\
\hline
\end{tabular}

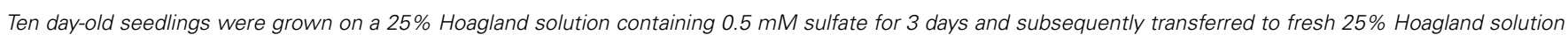

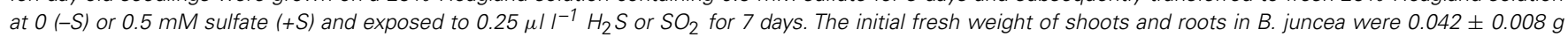

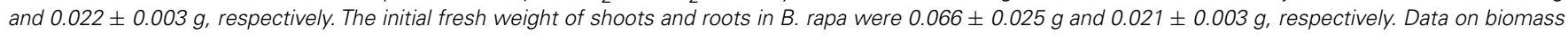

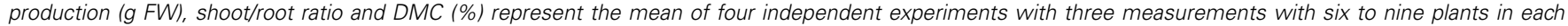
$( \pm S D)$. Different letters indicate significant differences between treatments $(P<0.01$, Student's t-test). 

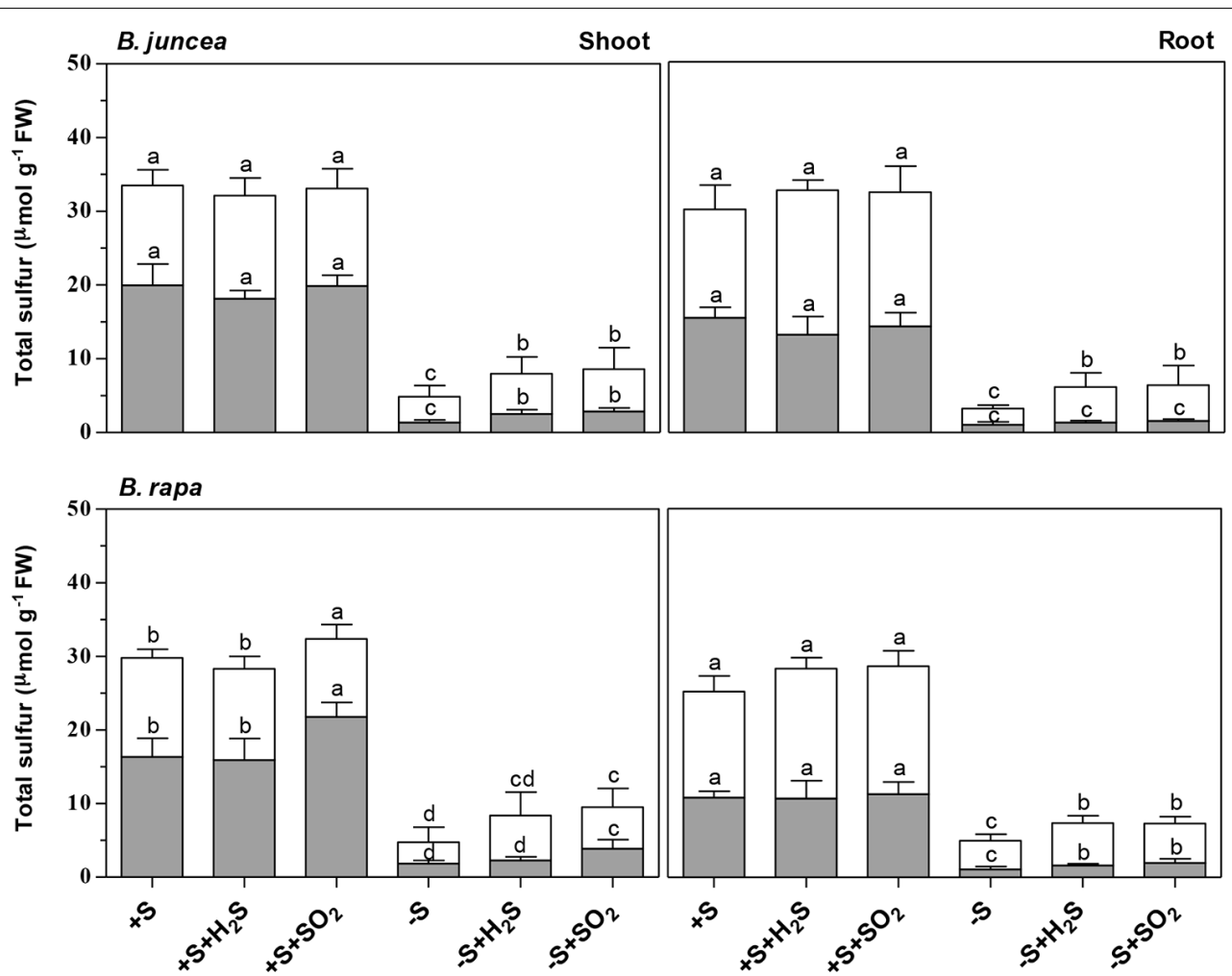

FIGURE 1 | Impact of $\mathrm{H}_{2} \mathrm{~S}, \mathrm{SO}_{2}$ and sulfate deprivation on total sulfur, sulfate and organic sulfur content of shoots and roots of B. juncea and B. rapa. For experimental details, see legends of Table 1. The sulfate and organic sulfur fraction is presented in gray and white, respectively. Data represent the mean of two experiments with three measurements with six to nine plants in each $( \pm S D)$. Different letters indicate significant differences between treatments $(P<0.01$, Student's $t$-test). did not affect the sulfur, sulfate, and organic sulfur content of both shoots and roots of $B$. juncea. In B. rapa, however, $\mathrm{SO}_{2}$ exposure resulted in a slight but significant increase in total sulfur content of the shoot, which could be attributed to an increase in the sulfate content, whereas the sulfur content of the root remained unaffected. Furthermore the organic sulfur content was hardly affected by the exposure of $B$. rapa to $\mathrm{SO}_{2}$ in sulfate-sufficient conditions in both shoots and roots (Figure 1).

Sulfate deprivation resulted in a decreased biomass production of B. juncea and B. rapa (Table 1). However, shoot growth was more affected than root growth, resulting in a decrease on the shoot to root ratio upon sulfate deprivation. A 7-day sulfate deprivation resulted in 53 and $68 \%$ decreases of shoot biomass production of $B$. juncea and $B$. rapa, respectively. The root biomass production of $B$. juncea was not affected and that of $B$. rapa was reduced by $32 \%$. The DMC of the shoot of B. juncea was not affected by sulfate deprivation, but that of the root was decreased (Table 1). However, the DMC of the shoot of B. rapa was significantly increased, whereas that of the root was hardly affected (Table 1). Sulfate deprivation resulted in strongly decreased total sulfur, sulfate, and organic sulfur contents of shoots and roots of both species (Figure 1). In particular, the proportion of sulfate was diminished and utilized for the synthesis for organic sulfur compounds (Figure 1).
Exposure of plants to $0.25 \mu \mathrm{ll}^{-1} \mathrm{H}_{2} \mathrm{~S}$ and $\mathrm{SO}_{2}$ alleviated either fully (B. juncea) or largely (B. rapa) the decrease in shoot biomass production upon sulfate-deprivation, demonstrating that the foliarly absorbed sulfur gases replaced sulfate taken up by the root as a sulfur source for growth. However, the root biomass production of $\mathrm{H}_{2} \mathrm{~S}$ and $\mathrm{SO}_{2}$ exposed sulfate-deprived plants was even higher than that of plants at sulfate-sufficient conditions (Table 1). As a consequence, the shoot to root ratio was lower for sulfate-deprived $\mathrm{H}_{2} \mathrm{~S}$ and $\mathrm{SO}_{2}$ exposed plants than that of sulfate-sufficient plants. The shoot DMC of B. juncea for sulfatedeprived plants was hardly affected by $\mathrm{H}_{2} \mathrm{~S}$ and $\mathrm{SO}_{2}$ exposure and was quite similar to that of sulfate-sufficient plants (Table 1). The DMC of the root sulfate-deprived $\mathrm{H}_{2} \mathrm{~S}$ and $\mathrm{SO}_{2}$ exposed plants remained lower than that of sulfate-sufficient plants. The DMC of the shoots and roots of sulfate-deprived $B$. rapa was only slightly affected by $\mathrm{H}_{2} \mathrm{~S}$ and $\mathrm{SO}_{2}$ exposure and was quite similar to that of sulfate-sufficient plants (Table 1).

Both $\mathrm{H}_{2} \mathrm{~S}$ and $\mathrm{SO}_{2}$ exposure of sulfate-deprived $B$. juncea and $B$. rapa resulted in an increase in total sulfur and organic sulfur content of both shoots and roots (Figure 1) however the overall total sulfur content was almost threefold and 2.5fold lower than that observed for sulfate-sufficient $B$. juncea and B. rapa, respectively. The low total sulfur content could only in part be ascribed to a low apparent sulfate content upon sulfate-deprivation. 
IMPACT OF ATMOSPHERIC AND PEDOSPHERIC SULFUR NUTRITION ON GLUCOSINOLATE CONTENT

There were considerable differences in the content of glucosinolates of shoots of $B$. juncea and B. rapa seedlings. The glucosinolate content of the shoot of $B$. juncea was twofold higher than that in the shoot of $B$. rapa, expressed either on a fresh weight basis and or relative to organic sulfur (Figure 2). However, the glucosinolate content of the roots of both Brassica species was quite similar. Neither $\mathrm{H}_{2} \mathrm{~S}$ and $\mathrm{SO}_{2}$ exposure affected the glucosinolate content of shoots and roots of B. juncea and B. rapa, expressed either on a fresh weight or organic sulfur basis (Figure 2).

A 7-day sulfate deprivation resulted in 50\% decrease in the glucosinolate content of both shoots and roots of B. juncea and a 20 and $45 \%$ decrease in content of the shoots and roots
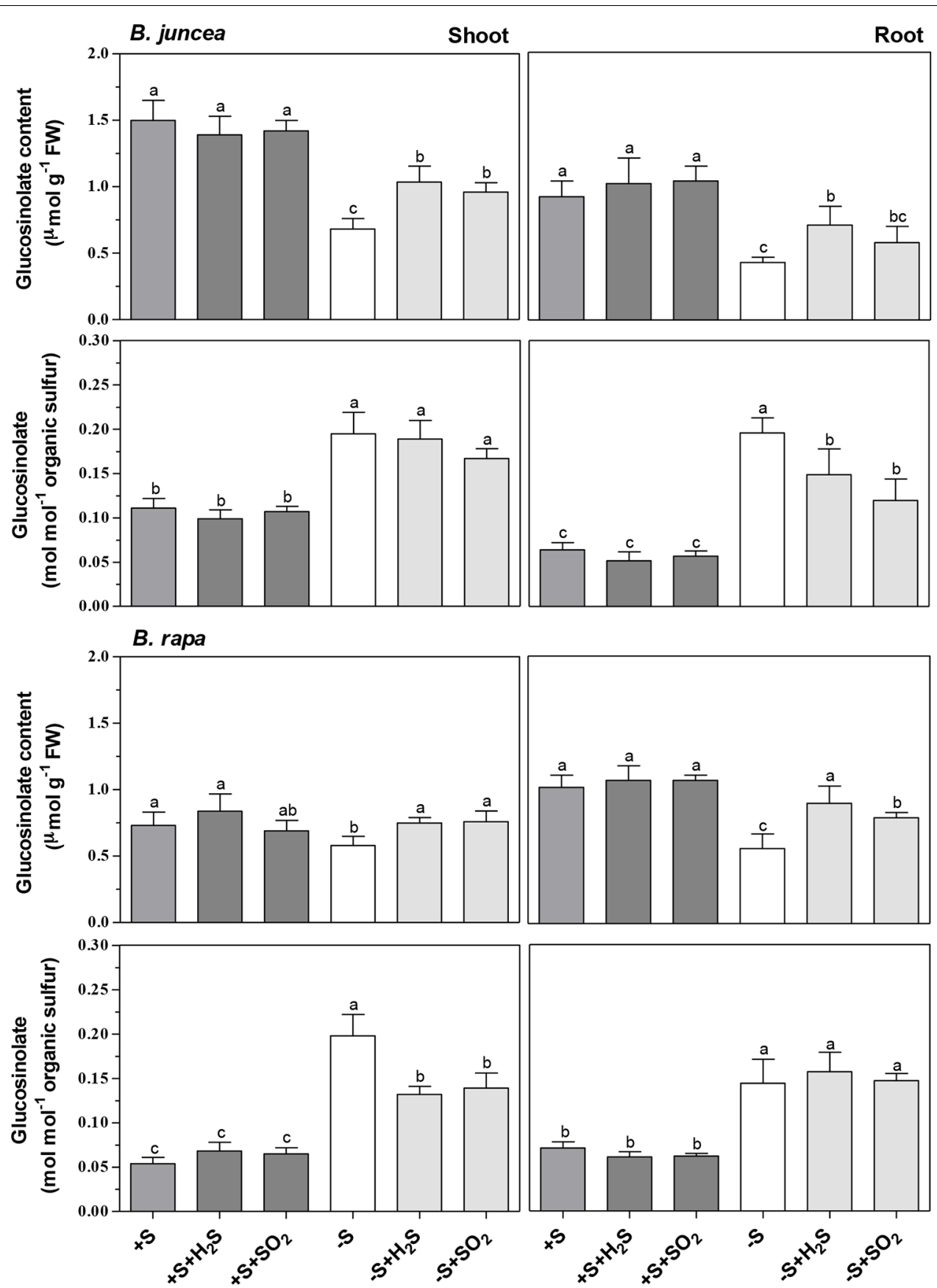

FIGURE 2 | Impact of $\mathrm{H}_{2} \mathrm{~S}, \mathrm{SO}_{2}$ and sulfate deprivation on glucosinolate content of shoots and roots of $\boldsymbol{B}$. juncea and $\boldsymbol{B}$. rapa. For experimental details, see legends of Table 1. Data represent the mean of two experiments with three measurements with nine plants in each $( \pm S D)$. Different letters indicate significant differences between treatments $(P<0.01$, Student's t-test). 
of $B$. rapa, respectively (Figure 2). $\mathrm{H}_{2} \mathrm{~S}$ and $\mathrm{SO}_{2}$ exposure of sulfate-deprived plants alleviated almost fully the decrease in glucosinolate contents of shoot and roots of $B$. rapa, and their contents were quite similar (except that of the roots of sulfate-deprived $\mathrm{SO}_{2}$-exposed plants) to that of sulfate-sufficient plants (Figure 2). $\mathrm{H}_{2} \mathrm{~S}$ and $\mathrm{SO}_{2}$ exposure of sulfate-deprived $B$. juncea also resulted in a higher glucosinolate content of both shoots and roots. However, their contents were significantly lower than that observed in sulfate-sufficient plants (Figure 2). On an organic sulfur basis, however, the glucosinolate content of shoots and roots of sulfate-deprived of B. juncea and B. rapa, both in absence and presence of $\mathrm{H}_{2} \mathrm{~S}$ or $\mathrm{SO}_{2}$, was always higher than that observed in sulfate-sufficient plants (Figure 2). This indicated that proportionally, the content of other organic sulfur compounds (e.g., proteins), was more affected by sulfate deprivation than that of the glucosinolates, even in presence of foliarly absorbed $\mathrm{H}_{2} \mathrm{~S}$ or $\mathrm{SO}_{2}$ as alternative sulfur sources for growth.

\section{IMPACT OF ATMOSPHERIC AND PEDOSPHERIC SULFUR NUTRITION ON THE ACTIVITY AND EXPRESSION OF MYROSINASE}

There were considerable differences in the activity of myrosinase in shoots and roots of B. juncea and B. rapa seedlings (Table 2). Both shoots and roots of $B$. juncea were characterized by a high myrosinase activity. B. rapa, however, was characterized by very low and hardly detectible myrosinase activity in the shoot and high activity in the root, the latter being quite similar to that observed in B. juncea. If glucoberin was used as substrate instead of sinigrin, comparable myrosinase activities were observed (data not presented). This demonstrated that the differences in activity of this enzyme in the shoots of $B$. juncea and B. rapa were unlikely to be explained by differences in substrate selectivity. Additionally the transcript level of myrosinase was substantially lower in shoots of $B$. rapa than that of $B$. juncea (Figure 3). In sulfate-sufficient conditions, $\mathrm{H}_{2} \mathrm{~S}$ and $\mathrm{SO}_{2}$ exposure did not affect the activities of myrosinase enzyme of shoots and roots of B. juncea and B. rapa (Table 2) or the expression of the gene in the shoots (Figure 3 ).

A 7-day sulfate deprivation resulted in a decrease in myrosinase activity in roots of $B$. juncea and B. rapa (expressed on a fresh weight basis), while activity in the shoot of $B$. juncea was not affected (Table 2). However, the transcript levels of myrosinase in shoots of both $B$. juncea and B. rapa were decreased upon sulfate deprivation (Figure 3). Sulfate deprivation resulted in a decrease in soluble protein content of shoots and roots of both species (Table 2). If the myrosinase activity in the roots of both species was expressed on a protein basis, then specific activity remained unaffected and was around $90 \mathrm{nmol} \mathrm{mg}^{-1}$ protein $\mathrm{min}^{-1}$, whereas in the shoot of $B$. juncea its activity increased from 23 in sulfate-sufficient to $39 \mathrm{nmol} \mathrm{mg}^{-1}$ protein $\mathrm{min}^{-1}$ in sulfatedeprived plants. Exposure of sulfate-deprived plants to $\mathrm{H}_{2} \mathrm{~S}$ or $\mathrm{SO}_{2}$ resulted in an increase in soluble protein content, although it hardly affected the myrosinase activity in shoots and roots of $B$. juncea and B. rapa (expressed on a fresh weight basis; Table 2). $\mathrm{H}_{2} \mathrm{~S}$ or $\mathrm{SO}_{2}$ exposure of sulfate-deprived plants did not affect the myrosinase transcript level in the shoot of $B$. juncea, whereas it was increased in the shoot of B. rapa (Figure 3).

\section{DISCUSSION}

Brassicaceae are fast growing species characterized by a relatively high sulfur requirement (Westerman et al., 2001a; Castro et al., 2003; Yang et al., 2006a,b). Under the experimental conditions used here, $B$. juncea and $B$. rapa seedlings had a relative growth

Table 2 | Impact of $\mathrm{H}_{2} \mathrm{~S}, \mathrm{SO}_{2}$ and sulfate deprivation on myrosinase activity and water-soluble protein content of shoots and roots of $B$. juncea and $B$. rapa. For experimental details see legends of Table 1 .

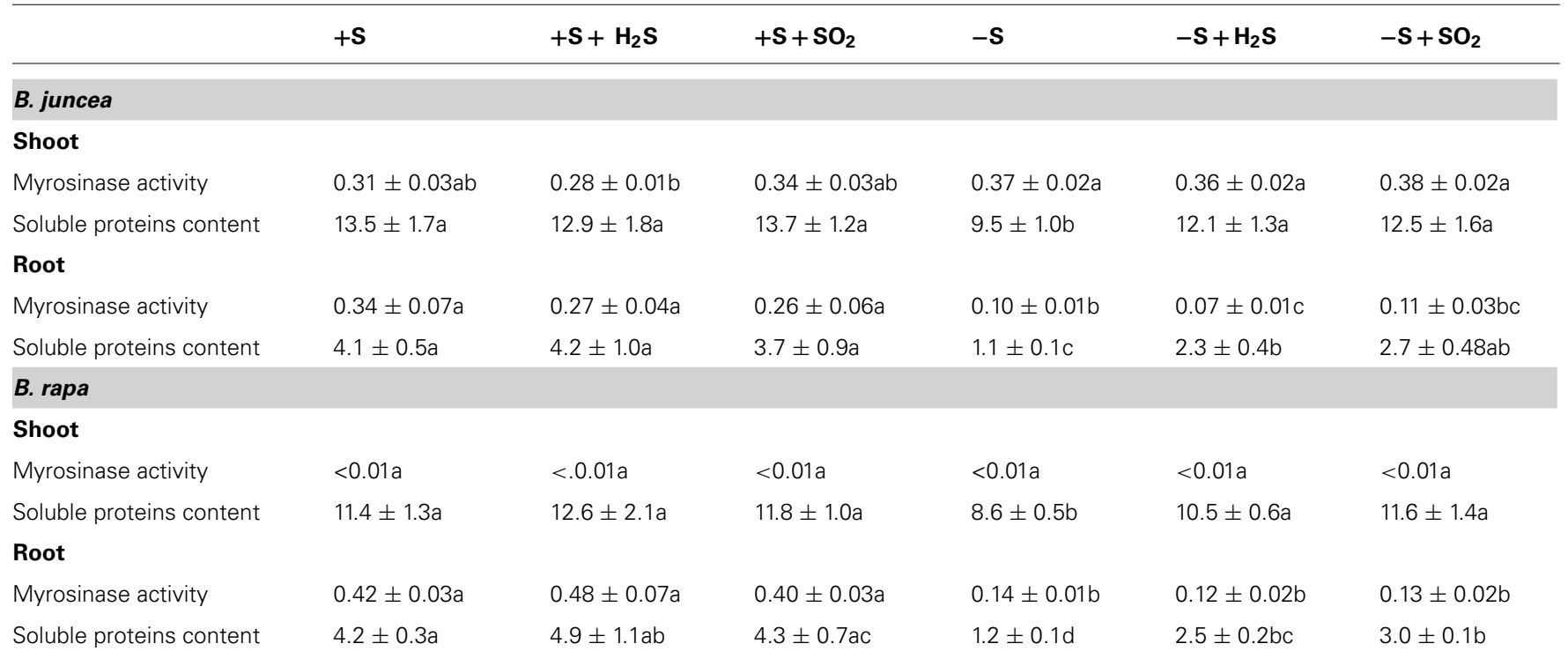

For experimental details see legends of Table 1. Data on myrosinase activity ( $\mathrm{nmol} \mathrm{mg}^{-1}$ fresh weight $\mathrm{min}^{-1}$ ) and soluble protein content ( $\mathrm{mg} \mathrm{g}^{-1}$ fresh weight)

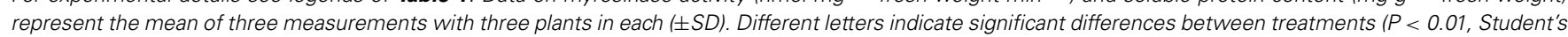
t-test). 


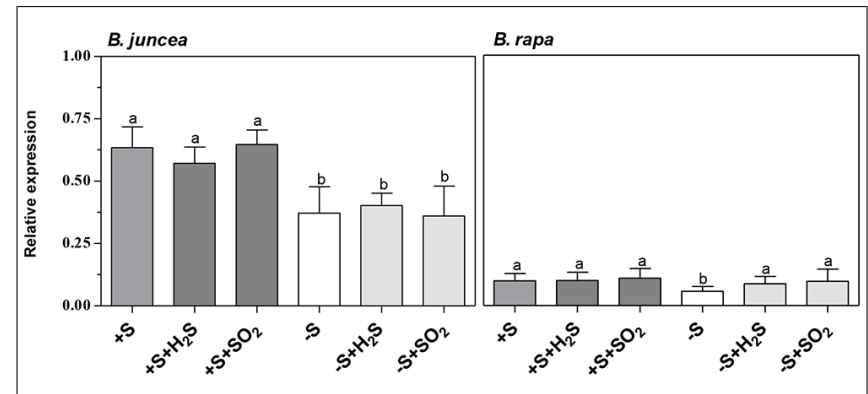

FIGURE 3 | Impact of $\mathrm{H}_{2} \mathrm{~S}, \mathrm{SO}_{2}$ and sulfate deprivation on transcript levels of myrosinase in shoots of $B$. juncea and $B$. rapa. For

experimental details, see legends of Table 1. Relative gene expression of myrosinase was determined by qRT-PCR and the mRNA levels were compared to actin. Data on relative expression in each treatment represent the mean of three measurements with three shoots in each $( \pm S D)$. Different letters indicate significant differences between treatments $(P<0.01$, Student's $t$-test $)$

rate of 36.9 and $38.6 \%$ day $^{-1}$ and a plant sulfur content of 33.4 and $29.4 \mu \mathrm{mol} \mathrm{g}^{-1}$ fresh weight (340 and $272 \mu \mathrm{mol} \mathrm{g}^{-1}$ dry weight), respectively (data derived from Table 1; Figure 1). Seedlings of Brassicaceae are often characterized by a relatively high ratio of sulfate to organic sulfur. For instance, in B. oleracea the sulfate content may account for more than $80 \%$ of the total sulfur in the shoot (Westerman et al., 2001b; Castro et al., 2003; Yang et al., $2006 a, b)$. The sulfate content accounted for 60 and 50\% of total sulfur in the shoots and roots of B. juncea, and for 55 and $43 \%$ in shoots and roots of B. rapa, respectively. Brassica species are also characterized by a relatively high content of secondary sulfur compounds, viz. glucosinolates, which strongly varies between species, and may in seedlings account for 10 to $23 \%$ of the organic sulfur fraction (Castro et al., 2004). The glucosinolates content of the shoot of $B$. juncea was twofold higher than that in the shoot of B. rapa and accounted for up to $30 \%$ of the organic sulfur fraction (on the basis of $3 \mathrm{~S}$ groups per molecule), presuming that the aliphatic glucosinolates are the major secondary sulfur compounds present in Brassica (Kushad etal., 1999; Van Dam et al., 2003; Cartea et al., 2008). In the root, content appeared to be quite similar in both species, where it accounted for $15 \%$ of the organic sulfur fraction.

Atmospheric sulfur gases, viz. $\mathrm{SO}_{2}$ and $\mathrm{H}_{2} \mathrm{~S}$, may be taken up by the plant shoot and used as a sulfur source for growth (De Kok et al., 2007). The foliar uptake of $\mathrm{SO}_{2}$ is determined by its chemical/physical properties, viz. rapid dissociation in the water of the mesophyll apoplast, which is beyond regulatory control (De Kok et al., 2007). The foliar uptake of $\mathrm{H}_{2} \mathrm{~S}$, however, is largely determined by the rate of metabolism in the shoot (De Kok et al., 2007). Exposure of B. juncea and B. rapa to $0.25 \mu \mathrm{l}^{-1} \mathrm{SO}_{2}$ and $\mathrm{H}_{2} \mathrm{~S}$ hardly affected the total sulfur content of both species. There was only a slight increase in the shoot total sulfur content of $\mathrm{SO}_{2}$ exposed B. rapa, which could be attributed to an enhanced sulfate content. However, it was evident that at this atmospheric sulfur concentration of $\mathrm{SO}_{2}$ and $\mathrm{H}_{2} \mathrm{~S}$, plants were able to take up sufficient sulfur by the shoot to fully cover their organic sulfur requirement for plant growth. Since, the decrease in biomass production upon sulfate-deprivation was completely alleviated by $\mathrm{SO}_{2}$ and $\mathrm{H}_{2} \mathrm{~S}$ exposure. Similarly to previous observations, sulfatedeprived plants invested relatively more biomass in their roots than those grown under sulfate-sufficient conditions, even upon $\mathrm{SO}_{2}$ and $\mathrm{H}_{2} \mathrm{~S}$ exposure (Buchner et al., 2004; Yang et al., 2006a; Koralewska et al., 2008; Shahbaz et al., 2014).

In greenhouse and field experiments involving soil, hydroponic, and tissue culture media, sulfur fertilization generally resulted in an increased glucosinolate content of Brassica (Falk et al., 2007). However, $\mathrm{SO}_{2}$ and $\mathrm{H}_{2} \mathrm{~S}$ exposure of $B$. juncea and $B$. rapa seedlings did not affect the glucosinolate content of the shoots and roots, either expressed on fresh weight or organic sulfur basis. This demonstrated that these sulfur compounds did not form a sink for excessive supplied atmospheric sulfur. $\mathrm{SO}_{2}$ and $\mathrm{H}_{2} \mathrm{~S}$ exposure of Brassica generally resulted in enhanced levels of water-soluble, non-protein thiol compounds in the shoot (De Kok and Tausz, 2001; Westerman etal., 2001a; Buchner et al., 2004; Yang et al., 2006a; Koralewska et al., 2008; Shahbaz et al., 2014), which could be ascribed to an accumulation of cysteine and glutathione (De Kok and Tausz, 2001; De Kok et al., 2007). Apparently, an enhanced availability of these thiol compounds, which also function as reduced sulfur donors in the synthesis of glucosinolates (Schnug, 1990, 1993; Halkier and Gershenzon, 2006; Falk et al., 2007) did not affect the rate of synthesis of these secondary sulfur compounds in the shoot. Allium species (e.g., onion, garlic, leek) also contain secondary sulfur compounds viz. $\gamma$-glutamyl peptides and allins, which are synthesized from cysteine, via $\gamma$-glutamylcysteine or glutathione. In contrast to observations with glucosinolates, in Brassica the content of these secondary sulfur compounds, their precursors and/or degradation products were strongly enhanced in shoots of $\mathrm{H}_{2}$ S-exposed Allium (Durenkamp and De Kok, 2002, 2004; Durenkamp et al., 2005). $\mathrm{SO}_{2}$ exposure, however, hardly affected the levels of these secondary sulfur compounds in Allium (Durenkamp et al., 2005).

Exposure of Brassica to $\mathrm{H}_{2} \mathrm{~S}$ resulted in a strong decrease in expression, in protein level and in enzyme activity of APS reductase in the shoot (Westerman et al., 2000a,b, 2001a,b; Durenkamp et al., 2007; Koralewska et al., 2008; Shahbaz et al., 2014). Evidently, a down-regulation of APS reductase, the key enzyme controlling the flux through the sulfate reduction pathway, did not affect the synthesis of glucosinolates via the channeling of the APS through the APS kinase/sulfotransferase pathway. The latter is essential for the synthesis of the sulfated moiety of the glucosinolates (Kopriva etal., 2012). This demonstrated that the synthesis of glucosinolates in the shoot of Brassica seedlings was under strict regulatory control and was not affected by an excess supply of foliarly absorbed sulfur, irrespective of the differences in content of these secondary sulfur compounds between $B$. juncea and $B$. rapa.

Sulfate deprivation resulted in a strong decrease in the total sulfur content of shoots and roots of B. juncea and B. rapa, which was for the greater part due to a decrease in sulfate content. It has been observed that in Arabidopsis sulfur deficiency resulted in a repression of the glucosinolate biosynthesis genes (Hirai et al., 2005). There was also a strong decrease in the glucosinolate content of both shoots and roots of B. juncea and B. rapa upon sulfate deprivation. However, the decrease in glucosinolate content was lower than that of the other organic sulfur compounds, resulting 
in an increase in its content expressed on organic sulfur basis. Sulfur in proteins generally accounts for more than $80 \%$ of the organic sulfur content (Stulen and De Kok, 1993). Apparently, sulfate deprivation had a higher impact on the proportion of sulfur in proteins in Brassica than the other organic sulfur compounds viz. glucosinolates. It has been observed that in shoots, sulfate deprivation resulted in a degradation of Rubisco, which proportion may account for $25-60 \%$ of the soluble proteins in photosynthetic tissue (Ferreira and Teixeira, 1992; Gilbert et al., 1997). The proportion of sulfur in the glucosinolates in both shoots and roots of B. juncea and B. rapa in sulfate-deprived plants exceeded 50\% of the total organic sulfur fraction (on the basis of $3 \mathrm{~S}$ groups per molecule). These results indicated that glucosinolates cannot be considered as sulfur storage compounds and they were not utilized in the re-distribution of sulfur in B. juncea and B. rapa seedlings upon sulfate deprivation.

$\mathrm{SO}_{2}$ and $\mathrm{H}_{2} \mathrm{~S}$ exposure resulted in an increase in total sulfur content of shoots and roots of the two Brassica species upon sulfate deprivation, which was mainly due to an increase in the organic sulfur fraction. Likewise, there was an increase in glucosinolate content, though the levels were always lower than that of sulfate-sufficient plants. However, on an organic sulfur basis, the glucosinolate content in both shoots and roots was substantially higher than that observed in sulfate-sufficient plants upon $\mathrm{SO}_{2}$ and $\mathrm{H}_{2} \mathrm{~S}$ exposure. Apparently in sulfate-deprived conditions, a relatively greater proportion of atmospheric sulfur taken up by the shoot was used for the synthesis of glucosinolates than that of other organic sulfur compounds, e.g., proteins. Roots of sulfate-deprived plants depended on sulfur transported form shoot to root upon exposure to $\mathrm{SO}_{2}$ and $\mathrm{H}_{2} \mathrm{~S}$, although in which form the sulfur was transported from shoot to root under these conditions remains unknown. Organic sulfur may be transported in the phloem from source to sink, e.g., from shoot to root in different forms, viz. glutathione, $S$-methylmethionine or as glucosinolates (Brunold and Rennenberg, 1997; Bourgis et al., 1999; Grubb and Abel, 2006; Rennenberg and Herschbach, 2014).

Glucosinolates may be involved in plant defense against pathogens and herbivory (Bones et al., 1994; Brader et al., 2006; Grubb and Abel, 2006; Bednarek et al., 2011; Frerigmann et al., 2012; Schiestl, 2014) and is dependent upon breakdown activated by tissue damage and catalyzed by myrosinase (Bones et al., 1994; Grubb and Abel, 2006; Clay et al., 2009; Kissen and Bones, 2009; Kissen et al., 2009; Ahuja et al., 2010). Moreover, it has been suggested that myrosinase might have significance in the redistribution of sulfur in plants under sulfur-deprived conditions (Schnug, 1990; Hirai et al., 2004, 2005; Bloem et al., 2007; Falk et al., 2007).

There was a direct relation between the content of glucosinolates and the transcript level and activity of myrosinase in the shoot of $B$. juncea and B. rapa. Both low glucosinolate content and a low transcript level of myrosinase and activity of this enzyme characterized the shoot of the latter species. Even though myrosinase activity was decreased in both roots of sulfatedeprived $B$. juncea and $B$. rapa, $\mathrm{SO}_{2}$ and $\mathrm{H}_{2} \mathrm{~S}$ exposure hardly affected the activity in shoots and roots under either sulfatesufficient or sulfate-deprived conditions, despite an increase in glucosinolate content upon exposure in sulfate-deprived plants. There was apparently no direct co-regulation between the content of glucosinolates and the activity of myrosinase. From the current observation that the sulfur of glucosinolates was hardly re-distributed upon sulfate deprivation, the significance of myrosinase in the in situ turnover of these secondary sulfur compounds needs to be questioned.

\section{AUTHOR CONTRIBUTIONS}

Tahereh Aghajanzadeh, Malcolm J. Hawkesford, and Luit J. De Kok designed the research. Tahereh Aghajanzadeh carried out the experiments and analyzed the data. All authors contributed to writing the manuscript. Luit J. De Kok and Malcolm J. Hawkesford supervised the project.

\section{ACKNOWLEDGMENTS}

Rothamsted Research is supported via the 20:20 Wheat ${ }^{\circledR}$ Programme by the UK Biotechnology and Biological Sciences Research Council. We wish to thank Helen Jenkins and C. Elisabeth E. Stuiver for critically reading of the manuscript.

\section{REFERENCES}

Ahuja, I., Rohloff, J., and Bones, A. M. (2010). Defence Mechanisms of Brassicaceae: implications for plant-insect interactions and potential for integrated pest management. Agron. Sustain. Dev. 30, 311-348. doi: 10.1051/Agro/ 2009025

Andersson, D., Chakrabarty, R., Bejai, S., Zhang, J., Rask, L., and Meijer, J. (2009). Myrosinases from root and leaves of Arabidopsis thaliana have different catalytic properties. Phytochemistry 70, 1345-1354. doi: 10.1016/j.phytochem.2009. 07.036

Antonious, G., Bomford, M., and Vincelli, P. (2009). Screening Brassica species for glucosinolate content. J. Environ. Sci. Health B 44, 311-316. doi: 10.1080/03601230902728476

Bednarek, P., Piślewska-Bednarek, M., van Themaat, E. V. L., Maddula, R. K., Svatoš, A., and Schulze-Lefert, P. (2011). Conservation and clade-specific diversification of pathogen-inducible tryptophan and indole glucosinolate metabolism in Arabidopsis thaliana relatives. New Phytol. 192, 713-726. doi: 10.1111/j.14698137.2011.03824.x

Bloem, E., Haneklaus, S., and Schnug, E. (2007). Changes in the sulphur and glucosinolate content of developing pods and seeds of oilseed rape (Brassica napus L.) in relation to different cultivars. Landbauforsch. Völk. 57, 297-306.

Bones, A. M., and Rossiter, J. T. (1996). The myrosinase-glucosinolate system, its organisation and biochemistry. Physiol. plant. 96, 194-208. doi: 10.1111/j.13993054.1996.tb00497.x

Bones, A. M., and Rossiter, J. T. (2006). The enzymic and chemically induced decomposition of glucosinolates. Phytochemistry 67, 1053-1067. doi: 10.1016/j.phytochem.2006.02.024

Bones, A., Visvalingam, S., and Thangstad, O. (1994). Sulphate can induce differential expression of thioglucoside glucohydrolases (myrosinases). Planta 193, 558-566. doi: 10.1007/BF02411562

Bourgis, F., Roje, S., Nuccio, M. L., Fisher, D. B., Tarczynski, M. C., Li, C., et al. (1999). S-methylmethionine plays a major role in phloem sulfur transport and is synthesized by a novel type of methyltransferase. Plant Cell 11, 1485-1497. doi: 10.1105/tpc.11.8.1485

Brader, G., Mikkelsen, M. D., Halkier, B. A., and Palva, E. T. (2006). Altering glucosinolate profiles modulates disease resistance in plants. Plant J. 46, 758-767. doi: 10.1111/j.1365-313X.2006.02743.x

Bradford, M. M. (1976). A rapid and sensitive method for the quantitation of microgram quantities of protein utilizing the principle of protein-dye binding. Anal. Biochem. 72, 248-254. doi: 10.1016/0003-2697(76)90527-3

Brunold, C., and Rennenberg, H. (1997). "Regulation of sulfur metabolism in plants: first molecular approaches," in Progress in Botany, eds H. D. Behnke, U. Lüttge, H. C. M. Karl Esser, J. W. Kadereit, and M. Runge (Berlin: Springer) 58, $164-186$. 
Buchner, P., Stuiver, C. E. E., Westerman, S., Wirtz, M., Hell, R., Hawkesford, M. J., et al. (2004). Regulation of sulfate uptake and expression of sulfate transporter genes in Brassica oleracea as affected by atmospheric $\mathrm{H}_{2} \mathrm{~S}$ and pedospheric sulfate nutrition. Plant Physiol. 136, 3396-3408. doi: 10.1104/pp.104.046441

Cartea, M. E., Velasco, P., Obregón, S., Padilla, G., and De Haro, A. (2008). Seasonal variation in glucosinolate content in Brassica oleracea crops grown in northwestern Spain. Phytochemistry 69, 403-410. doi: 10.1016/j.phytochem.2007.08.014

Castro, A., Aires, A., Rosa, E., Bloem, E., and Stulen, I. (2004). Distribution of glucosinolates in Brassica oleracea cultivars. Phyton (B Aires) 44, 133-143.

Castro, A., Stulen, I., and De Kok, L. J. (2003). "Nitrogen and sulfur requirement of Brassica oleracea L. cultivars," in Sulfur Transport and Assimilation in Plants, eds J. C. Davidian, D. Grill, L. J. De Kok, I. Stulen, M. J. Hawkesford, E. Schnug, et al. (Leiden: Backhuys Publishers), 181-183.

Clay, N. K., Adio, A. M., Denoux, C., Jander, G., and Ausubel, F. M. (2009). Glucosinolate metabolites required for an Arabidopsis innate immune response. Science 323, 95-101. doi: 10.1126/science.1164627

De Kok, L. J., Durenkamp, M., Yang, L., and Stulen, I. (2007). "Atmospheric sulfur," in Sulfur in Plants: An Ecological Perspective, eds M. J. Hawkesford and L. J. De Kok (Berlin: Springer), 91-106. doi: 10.1007/978-1-4020-5887-5_5

De Kok, L. J., Stuiver, C. E. E., Westerman, S., and Stulen, I. (2000a). "Atmospheric $\mathrm{H}_{2} \mathrm{~S}$ pollution - deposition and impact on sulphur metabolism in plants," in Environmental Stress: Indication, Mitigation and Eco-Conservation, eds M. Yunus, N. Singh, and L. J. De Kok (Berlin: Springer), 135-141.

De Kok, L. J., Westerman, S., Stuiver, C. E. E., and Stulen, I. (2000b). “Atmospheric $\mathrm{H}_{2} \mathrm{~S}$ as plant sulphur source: interaction with pedospheric sulfur nutrition - a case study with Brassica oleracea L.," in Sulphur Nutrition and Sulphur Assimilation in Higher Plants: Molecular, Biochemical and Physiological Aspects, eds C. Brunold, H. Rennenberg, L. J. De Kok, I. Stulen, and J.-C. Davidian (Bern: Paul Haupt Verlag), 41-55.

De Kok, L. J., Stuiver, C. E. E., Westerman, S., and Stulen, I. (2002). "Elevated level of hydrogen sulphide in the plant environment: nutrient or toxin," in Air Pollution and Plant Biotechnology-Prospects for Phytomonitoring and Phytoremediation, eds K. Omasa, H. Saji, S. Youssefian, and N. Kondo (Tokyo: Springer-Verlag), 201219.

De Kok, L. J., and Tausz, M. (2001). "The role of glutathione in plant reaction and adaptation to air pollutants," in Significance of Glutathione to Plant Adaptation to the Environment, eds D. Grill, M. Tausz, and L. J. De Kok (Dordrecht: Kluwer Academic Publishers), 185-201.

De Kok, L. J., Yang, L., Stuiver, C. E. E., and Stulen, I. (2009). "Negative versus positive functional plant responses to air pollution: a study establishing causeeffect relationship of $\mathrm{SO}_{2}$ and $\mathrm{H}_{2} \mathrm{~S}$," in Air Quality and Ecological Impacts: Relating Sources to Effects, ed. A. K. Legge (Amsterdam: Elsevier), 121-134.

Del Carmen Martinez-Ballesta, M., Moreno, D., and Carvajal, M. (2013). The physiological importance of glucosinolates on plant response to abiotic stress in Brassica. Int. J. Mol. Sci. 14, 11607-11625. doi: 10.3390/ijms140611607

Durenkamp, M., and De Kok, L. J. (2002). The impact of atmospheric $\mathrm{H}_{2} \mathrm{~S}$ on growth and sulfur metabolism of Allium cepa L. Phyton (B Aires) 42, 55-63.

Durenkamp, M., and De Kok, L. J. (2004). Impact of pedospsheric and atmospheric sulphur nutrition on sulphur metabolism of Allium cepa L. a species with a potential sink capacity for secondary sulphur compounds. J. Exp. Bot. 55, 18211830. doi: 10.1093/jxb/erh187

Durenkamp, M., De Kok, L. J., and Kopriva, S. (2007). Adenosine 5'phosphosulphate reductase is regulated differently in Allium cepa L. and Brassica oleracea L. upon exposure to $\mathrm{H}_{2}$ S. J. Exp. Bot. 58, 1571-1579. doi: 10.1093/jxb/erm031

Durenkamp, M., Posthumus, F. S., Stuiver, C. E. E., and De Kok, L. J. (2005). "Metabolism of atmospheric sulfur gases in onion," in Plant Responses to Air Pollution and Global Change, eds K. Omasa, I. Nouchi, and L. J. De Kok (Tokyo: Springer-Verlag), 3-11.

Ernst, W. (1993). "Ecological aspects of sulfur in higher plants: The impact of $\mathrm{SO}_{2}$ and the evolution of the biosynthesis of organic sulfur compounds on populations and ecosystems," in Sulfur Nutrition and Sulfur Assimilation in Higher Plants; Regulatory, Agricultural and Environmental Aspects, eds L. J. De Kok, I. Stulen, H. Rennenberg, C. Brunold, and W. Rauser (The Hague: SPB Academic Publishing), 295-313.

Fahey, J. W., Zalcmann, A. T., and Talalay, P. (2001). The chemical diversity and distribution of glucosinolates and isothiocyanates among plants. Phytochemistry 56, 5-51. doi: 10.1016/S0031-9422(00)00316-2
Falk, K. L., Tokuhisa, J. G., and Gershenzon, J. (2007). The effect of sulfur nutrition on plant glucosinolate content: physiology and molecular mechanisms. Plant Biol. 9, 573-581. doi: 10.1055/s-2007-965431

Fenwick, G. R., Heaney, R. K., and Mullin, W. J. (1983). Glucosinolates and their breakdown products in food and food plants. Crit. Rev. Food Sci. Nutr. 18, 123-201. doi: 10.1080/10408398209527361

Ferreira, R. M., and Teixeira, A. R. (1992). Sulfur starvation in Lemna leads to degradation of ribulose-bisphosphate carboxylase without plant death. J. Biol. Chem. 267, 7253-7257.

Frerigmann, H., Böttcher, C., Baatout, D., and Gigolashvili, T. (2012). Glucosinolates are produced in trichomes of Arabidopsis thaliana. Front. Plant Sci. 3:242. doi: 10.3389/fpls.2012.00242

Gilbert, S., Clarkson, D. T., Cambridge, M., Lambers, H., and Hawkesford, M. J. (1997). Sulfate-deprivation has an early effect on the content of ribulose 1,5bisphosphate carboxylase/oxygenase and photosynthesis in young leaves of wheat. Plant Physiol. 115, 1231-1239. doi: 10.1104/pp.115.3.1231

Grubb, C. D., and Abel, S. (2006). Glucosinolate metabolism and its control. Trends Plant Sci. 11, 89-100. doi: 10.1016/j.tplants.2005.12.006

Gupta, S., Sangha, M. K., Kaur, G., Atwal, A. K., Kaur, P., Kumar, H., et al. (2012). Biochem. Anal. Biochem. 1, 121. doi: 10.4172/2161-1009.1000121

Halkier, B. A., and Du, L. (1997). The biosynthesis of glucosinolates. Trends Plant Sci. 2, 425-431. doi: 10.1016/S1360-1385(97)90026-1

Halkier, B. A., and Gershenzon, J. (2006). Biology and biochemistry of glucosinolates. Annu. Rev. Plant Biol. 57, 303-333. doi: 10.1146/annurev.arplant.57.032905. 105228

Heaney, R. K., and Fenwick, G. R. (1980). Glucosinolates in Brassica vegetables. analysis of 22 varieties of brussels sprouts (Brassica oleracea var. gemmifera). J. Sci. Food Agr. 31, 785-793. doi: 10.1002/jsfa.2740310808

Hirai, M. Y., Klein, M., Fujikawa, Y., Yano, M., Goodenowe, D. B., Yamazaki, Y., et al. (2005). Elucidation of gene-to-gene and metabolite-to-gene networks in Arabidopsis by integration of metabolomics and transcriptomics. J. Biol. Chem. 280, 25590-25595. doi: 10.1074/jbc.M502332200

Hirai, M. Y., Yano, M., Goodenowe, D. B., Kanaya, S., Kimura, T., Awazuhara, M., et al. (2004). Integration of transcriptomics and metabolomics for understanding of global responses to nutritional stresses in Arabidopsis thaliana. Proc. Natl. Acad. Sci. U.S.A. 101, 10205-10210. doi: 10.1073/pnas.0403218101

Ishida, M., Nagata, M., Ohara, T., Kakizaki, T., Hatekeyama, K., and Nishio, T. (2012). Small variation of glucosinolat composition in Japanese cultivars of radish (Raphanus sativus L.) requires simple quantitative analysis for breeding of glucosinolate component. Breed. Sci. 62, 63-70. doi: 10.1270/ jsbbs62.63

Jones, J. B. (1995). Determining total sulphur in plant tissue using the HACH kit spectrophotometer technique. Sulphur Agric. 19, 58-62.

Kirkegaard, J. A., and Sarwar, M. (1998). Biofumigation potential of Brassicas. Plant Soil 201, 71-89. doi: 10.1023/A:1004364713152

Kissen, R., and Bones, A. M. (2009). Nitrile-specifier proteins involved in glucosinolate hydrolysis in Arabidopsis thaliana. J. Biol. Chem. 284, 12057-12070. doi: 10.1074/jbc.M807500200

Kissen, R., Rossiter, J., and Bones, A. (2009). The 'mustard oil bomb': not so easy to assemble?! Localization, expression and distribution of the components of the myrosinase enzyme system. Photochem. Rev. 8, 69-86. doi: 10.1007/s11101-0089109-1

Kopriva, S., Mugford, S. J., Baraniecka, P., Lee, B., Matthewman, C. A., and Koprivova, A. (2012). Control of sulfur partitioning between primary and secondary metabolism in Arabidopsis. Front. Plant. Sci. 3:163. doi: 10.3389/fpls. 2012.00163

Koralewska, A., Stuiver, C. E. E., Posthumus, F. S., Kopriva, S., Hawkesford, M. J., and De Kok, L. J. (2008). Regulation of sulfate uptake, expression of the sulfate transporters Sultr 1;1 and Sultr 1;2, and APS reductase in Chinese cabbage (Brassica pekinensis) as affected by atmospheric $\mathrm{H}_{2} \mathrm{~S}$ nutrition and sulfate deprivation. Funct. Plant Biol. 35, 318-327. doi: 10.1071/FP07283

Kushad, M. M., Brown, A. F., Kurilich, A. C., Juvik, J. A., Klein, B. P., Wallig, M. A., et al. (1999). Variation of glucosinolates in vegetable crops of Brassica oleracea. J. Agric. Food Chem. 47,1541-1548. doi: 10.1021/jf980985s

Maas, F. M., Hoffmann, I., Van Harmelen, M. J., and De Kok, L. J. (1986). Refractometric determination of sulphate and other anions in plants separated by high-performance liquid chromatography. Plant Soil 91, 129-132. doi: 10.1007/BF02181825 
O’Callaghan, K. J., Stone, P. J., Hu, X., Griffiths, D. W., Michael, R., Davey, M. R., et al. (2000). Effects of glucosinolates and flavonoids on colonization of the roots of Brassica napus by Azorhizobium caulinodans ORS571. Appl. Environ. Microbiol. 66, 2185-2191. doi: 10.1128/AEM.66.5.2185-2191.2000

Rennenberg, H., and Herschbach, C. (2014). A detailed view on sulphur metabolism at the cellular and whole-plant level illustrates challenges in metabolite flux analyses. J. Exp. Biol. 65, 5711-5724. doi: 10.1093/jxb/eru315

Schiestl, F. P. (2014). Correlation analyses between volatiles and glucosinolates show no evidence for chemical defense signaling in Brassica rapa. Front. Ecol. Evol. 2:10. doi: $10.3389 /$ fevo.2014.00010

Schnug, E. (1990). "Glucosinolates - fundamental, environmental and agricultural aspects," in Sulfur Nutrition and Sulfur Assimilation in Higher Plant; Fundamental Environmental and Agricultural Aspects, eds H. Rennenberg, C. Brunold, L. J. De Kok, and I. Stulen (The Hague: SPB Academic Publishing), 97-106.

Schnug, E. (1993). "Physiological functions and environmental relevance of sulfurcontaining secondary metabolites," in Sulfur Nutrition and Sulfur Assimilation in Higher Plant; Regulatory Agricultural and Environmental Aspects, eds L. J. De Kok, I. Stulen, H. Rennenberg, C. Brunold, and W. E. Rauser (The Hague: SPB Academic Publishing), 179-190.

Shahbaz, M., Stuiver, C. E. E., Posthumus, F. S., Parmar, S., Hawkesford, M. J., and De Kok, L. G. (2014). Copper toxicity in Chinese cabbage is not influenced by plant sulphur status, but affects sulphur metabolism-related gene expression and the suggested regulatory metabolites. Plant Biol. 16, 68-78. doi: 10.1111/plb. 12019

Stulen, I., and De Kok, L. J. (1993). "Whole plant regulation of sulfate uptake and metabolism - a theoretical approach and comparison with current ideas on regulation of nitrogen metabolism," in Sulfur Nutrition and Assimilation in Higher Plants; Regulatory, Agricultural and Environmental Aspects, eds L. J. De Kok, I. Stulen, H. Rennenberg, C. Brunold, and W. E. Rauser (The Hague: SPB Academic Publishing), 77-91.

Tausz, M., De Kok, L. J., Stulen, I., and Grill, D. (1996). Physiological responses of Norway spruce trees to elevated $\mathrm{CO}_{2}$ and $\mathrm{SO}_{2}$. J. Plant Physiol. 148, 362-367. doi: 10.1016/S0176-1617(96)80266-5

Thies, W. (1982). Complex-formation between glucosinolates and tetrachloropalladate (II) and its utilization in plant breeding. Fette Seifen Anstrichmittel. 84, 388-342. doi: 10.1002/lipi.19820840903

Travers-Martin, N., Kuhlmann, F., and Müller, C. (2008). Revised determination of free and complexed myrosinase activities in plant extracts. Plant Physiol. Biochem. 46, 506-516. doi: 10.1016/j.plaphy.2008.02.008

Van Dam, N. M., Witjes, L., and Svatoš, A. (2003). Interactions between aboveground and belowground induction of glucosinolates in two wild Brassica species. New Phytol. 161, 801-810. doi: 10.1111/j.1469 8137.2004.00984.x
Verwoerd, T. C., Dekker, B. M., and Hoekema, A. (1989). A small-scale procedure for the rapid isolation of plant RNAs. Nucleic Acids Res. 17:2362. doi 10.1093/nar/17.6.2362

Westerman, S., Blake-Kalff, M. A. A., De Kok, L. J., Stuiver, C. E. E., and Stulen, I. (2001a). Sulfate uptake and utilization by two varieties of Brassica oleracea with different sulfur need as affected by atmospheric $\mathrm{H}_{2}$ S. Phyton (B Aires) 41, 49-62.

Westerman, S., Stulen, I., Suter, M., Brunold, C., and De Kok, L. J. (2001b). Atmospheric $\mathrm{H}_{2} \mathrm{~S}$ as sulfur source for Brassica oleracea: consequences for the activity of the enzymes of the assimilatory sulfate reduction pathway. Plant Physiol. Biochem. 39, 425-432. doi: 10.1016/S0981-9428(01)01258-X

Westerman, S., De Kok, L. J., and Stulen, I. (2000a). Interaction between metabolism of atmospheric $\mathrm{H}_{2} \mathrm{~S}$ in the shoot and sulfate uptake by the roots of curly kale (Brassica oleracea L). Physiol. Plant. 109, 443-449. doi: 10.1034/j.1399-3054.2000.100411.x

Westerman, S., Weidner, W., De Kok, L. J., and Stulen, I. (2000b). Effect of $\mathrm{H}_{2} \mathrm{~S}$ exposure on 35S-sulfate uptake, transport and utilization in curly kale. Phyton ( $B$ Aires) 40, 293-302.

Yang, L., Stulen, I., and De Kok, L. J. (2006a). Sulfur dioxide: relevance of toxic and nutritional effects for Chinese cabbage. Environ. Exp. Bot. 57, 236-245. doi: 10.1016/j.envexpbot.2005.06.002

Yang, L., Stulen, I., and De Kok, L. J. (2006b). Impact of sulfate nutrition on the utilization of atmospheric $\mathrm{SO}_{2}$ as sulfur source for Chinese cabbage. J. Plant Nutr. Soil Sci. 169, 529-534. doi: 10.1002/jpln.200520574

Conflict of Interest Statement: The authors declare that the research was conducted in the absence of any commercial or financial relationships that could be construed as a potential conflict of interest.

Received: 26 September 2014; accepted: 25 November 2014; published online: 19 December 2014.

Citation: Aghajanzadeh T, Hawkesford MJ and De Kok LJ (2014) The significance of glucosinolates for sulfur storage in Brassicaceae seedlings. Front. Plant Sci. 5:704. doi: 10.3389/fpls.2014.00704

This article was submitted to Plant Physiology, a section of the journal Frontiers in Plant Science.

Copyright (C) 2014 Aghajanzadeh, Hawkesford and De Kok. This is an open-access article distributed under the terms of the Creative Commons Attribution License (CC BY). The use, distribution or reproduction in other forums is permitted, provided the original author(s) or licensor are credited and that the original publication in this journal is cited, in accordance with accepted academic practice. No use, distribution or reproduction is permitted which does not comply with these terms. 